\title{
The role of invariant natural killer $T$ cells in dendritic cell licensing, cross-priming, and memory $\mathrm{CD}^{+} \mathrm{T}$ cell generation
}

\author{
Catherine Gottschalk, Elisabeth Mettke and Christian Kurts * \\ Institute of Experimental Immunology, Rheinische Friedrich-Wilhelms-University of Bonn, Bonn, Germany
}

New vaccination strategies focus on achieving $C D 8^{+} T$ cell $(C T L)$ immunity rather than on induction of protective antibody responses. While the requirement of $\mathrm{CD}^{+}{ }^{+} \mathrm{T}(\mathrm{Th})$ cell help in dendritic cell (DC) activation and licensing, and in CTL memory induction has been described in several disease models, CTL responses may occur in a Th cell help-independent manner. Invariant natural killer T cells (iNKT cells) can substitute for Th cell help and license DC as well. iNKT cells produce a broad spectrum of Th1 and Th2 cytokines, thereby inducing a similar set of costimulatory molecules and cytokines in DC. This form of licensing differs from Th cell help by inducing other chemokines, while Th cell-licensed DCs produce CCR5 ligands, iNKT cell-licensed DCs produce CCL17, which attracts $\mathrm{CCR} 4^{+} \mathrm{CD} 8^{+} \mathrm{T}$ cells for subsequent activation. It has recently been shown that iNKT cells do not only enhance immune responses against bacterial pathogens or parasites but also play a role in viral infections. The inclusion of iNKT cell ligands in influenza virus vaccines enhanced memory CTL generation and protective immunity in a mouse model. This review will focus on the role of iNKT cells in the cross-talk with cross-priming DC and memory $\mathrm{CD}^{+} \mathrm{T}$ cell formation.

Keywords: natural killer T cells, dendritic cells, licensing, memory, CD8 T cells, cross-presentation

\section{Classification of Natural Killer T Cells}

Natural killer T cells (NKT cells) are a subset of lymphocytes with innate and adaptive immune functions, for example, in tumor and anti-infectious defense (1). Their TCR can be either semiinvariant and encoded by a germline Valpha gene [type I invariant natural killer T cells (iNKT cells)] or may react against the self-antigen sulphatide using an oligoclonal TCR (type II NKT cells) (2-4). This review focusses on iNKT cells in dendritic cell (DC) licensing and T cell activation leading to a sustained memory response.

Invariant natural killer T cells respond to the marine sponge (Agelas mauritianus)-derived glycolipid alpha-galactosylceramide ( $\alpha$ GalCer) presented by the non-polymorphic CD1d molecule and respond by rapidly producing various cytokines $(5,6)$. Mostly studied in mice, they represent about $0.5 \%$ of $\mathrm{T}$ cells in the blood, $2 \%$ in secondary lymphatic organs, and over $30 \%$ of $\mathrm{T}$ cells in the liver. During inflammation and infection, iNKT cell numbers can strongly increase in numerous organs, e.g., the pancreas in type I diabetes or the lung in asthma $(7,8)$. In human blood, only $0.1-0.2 \%$ of T cells are iNKT cells, with $5 \times$ lower numbers than in mice (9). Recently, iNKT cells came into focus as promising targets for the development of vaccine adjuvants and immunotherapies, mostly 
TABLE 1 | Summary of iNKT cell activation studies in treatment of different diseases.

\begin{tabular}{|c|c|c|c|}
\hline Therapeutic target & Species studied & Outcome & Reference, remarks \\
\hline $\begin{array}{l}\text { Viral and bacterial } \\
\text { infections }\end{array}$ & Human, mouse & $\begin{array}{l}\text { Effective vaccination in mice; oral and nasal route } \\
\text { possible; no clear effect on chronic viral infections in } \\
\text { clinical trials shown }\end{array}$ & $(12-21)$ \\
\hline Parasites and fungi & Mouse & Enhanced vaccine effects in mice & $\begin{array}{l}(10,22-24) \\
\alpha \text { GalCer analogs were used in Ref. (10) (7DW8-5) and } \\
\text { Ref. (20) ( } \alpha \text {-C-GalCer) for NKT cell activation }\end{array}$ \\
\hline Tumors & Human, mouse & $\begin{array}{l}\text { Enhanced tumor protection and rejection in mice; clinical } \\
\text { trials show only moderate effects in humans }\end{array}$ & $\begin{array}{l}\text { (11, 14, 24-39) } \\
\text { Antigen-pulsed DC were transferred in Ref. (32), no } \\
\alpha \text { GalCer or analog was added. } \\
\alpha \text { GalCer and } \alpha-C-G a l C e r \text { were tested for tumor therapy } \\
\text { in Ref. (34) }\end{array}$ \\
\hline $\begin{array}{l}\text { Autoimmune } \\
\text { diseases }\end{array}$ & Mouse & $\begin{array}{l}\alpha \text { GalCer dose-dependent amelioration or aggravation of } \\
\text { autoimmune diseases; NKT cell hypo-responsiveness } \\
\text { involved in some cases }\end{array}$ & $\begin{array}{l}(8,40-52) \\
\text { Ref. (43) used OCH, a sphingosine-truncated analog of } \\
\alpha \text { GalCer for NKT cell activation }\end{array}$ \\
\hline
\end{tabular}

iNKT cells were activated by $\alpha$ GalCer treatment if not indicated otherwise.

in the field of cancer treatment and in autoimmune and inflammatory diseases (Table 1). Preclinical studies using $\alpha$ GalCer demonstrated moderate therapeutic activity by activating DCs and providing Th-like functions, generating $\mathrm{CD}^{+}{ }^{+}$cytotoxic $\mathrm{T}$ cell (CTL) and antibody responses. Currently, more potent $\alpha \mathrm{GalCer}$ analogs for iNKT cell activation are under investigation (10-13). Applying NKT cell immunization schemes in clinical settings is a promising therapeutic opportunity, but requires detailed knowledge on how iNKT cells activate DCs.

\section{iNKT Cell Activation, Subsets, and Cytokine Production}

Most knowledge on NKT cell activation came from the use of $\alpha \mathrm{GalCer}$, a strong and prototypical CD1-restricted agonist. In the last years, additional microbial-derived glycolipid ligands were identified, including $\alpha$-glucuronosylceramides (from Sphingomonas), cholesteryl $\alpha$-glucoside (from Helicobacter), or diacylglycerol-containing glycolipids (from Borrelia) (53, 54). These lead to sustained iNKT cell activation with inflammatory cytokine production that is independent of TLR stimulation, IL12 , or the recognition of endogenous antigens, hence relying only on engaging the invariant TCR. $\alpha$-glucuronosylceramide induces IFN $\gamma$ and IL-4 release similar to $\alpha$ GalCer (55-57). Both glycolipid antigens are structurally similar and can be recognized by the majority of mouse and human iNKT cells (58). Synthetic iNKT cell antigens have been and continue to be studied extensively for potential therapeutic application (59). However, iNKT cell activation may also promote allergic airway inflammation, and their overstimulation can induce iNKT cell anergy $(1,60)$.

Most microorganisms lack cognate iNKT cell antigens, hence activation of these cells relies on cytokines, such as IL-12 or IL-18, in conjunction with endogenous antigens. Even in the absence of TCR stimulation, some bacterial and viral infections induce a robust IL-12 response by DCs thereby activating iNKT cells in vivo $(61,62)$. Indirect iNKT cell activation results in the release of IFN $\gamma$ but usually not IL- 4 and is not restricted to TLR (62-65).
Analogous to Th cells subsets, different NKT cell subsets termed NKT1, NKT2, NKT17, $\mathrm{NKT}_{\mathrm{FH}}$, and NKT10 subsets were described with corresponding functionalities $(66,67)$. NKT17 cells produce the cytokines, IL-17 and IL-22, and are abundant in the lymph nodes, lungs, and skin of mice with airway neutrophilia induced by $\alpha$ GalCer (68). Recently, it was shown that iNKT17 cells are enriched in NOD mice, a mouse model for type I diabetes, which hint toward a possible role of those cells in disease development (69). iNKT17 cells rely on IL-7 for homeostasis and survival (70) and seem to require activation in the presence of TGF- $\beta$ and IL-1 $\beta$ (71). The recently described NKT10 subset can dampen inflammatory responses by IL-10 production and is enriched in adipose tissue, providing protection in obesityinduced inflammation (72).

\section{Dendritic Cell Maturation and CD8 ${ }^{+} \mathbf{T}$ Cell Cross-Priming}

Dendritic cells classically gather antigens in tissues and transport them into lymphatic organs, where they orchestrate the activation and differentiation of naïve $\mathrm{CD} 8^{+} \mathrm{T}$ cells into CTL. Recent work showed that some DCs remain in tissues in order to regulate immigrating effector $\mathrm{T}$ cell responses, which is important in the defense against infections and may also promote the progression of many immune-mediated diseases. The crosstalk of myeloid cells with other immune cells, such as $\mathrm{T}$ cells and innate lymphocytes, is especially important in this context. Cellular encounters are orchestrated by chemokines, cytokines, and cell surface molecules. Some DCs, especially the XCR1 ${ }^{+} \mathrm{DC}$ subset, are specialized in cross-presentation, which allows the presentation of extracellular antigens to activate CTL, a process important for immunity against tumors, viruses, and intracellular bacteria and for vaccination (73-76). Immunogenic crosspresentation, also referred to as cross-priming, requires the presence of pathogen-derived molecules (PAMPs) and/or of specific Th cells or NKT cells that mature the cross-presenting DC (77). This process is called "licensing," a term introduced by Lanzavecchia (78), and it aims at preventing unwanted immune answers against innocuous or self antigens. Licensing was first 
described by Matzinger, Heath, and Melief (79-81), and classically is mediated by CD40 ligand provided by specific $\mathrm{CD} 4^{+}$ helper $\mathrm{T}$ cells ( $\mathrm{Th}$ ). In addition to licensing, immunogenic $\mathrm{T}$ cell priming requires the DCs to mature, a process that results from sensing various PAMPs, including ligands for TLR, lectins, intracellular nucleotide-binding oligomerization domain receptors, or retinoic acid-induced genes (82-85). Major consequences of DC maturation are the upregulation of costimulatory molecules like CD80 and CD86, CD40, of MHC II and the production of pro-inflammatory cytokines, especially IL-12p70 and TNF. These consequences partially can result also from CD40-CD40L interactions, but it is not clearly defined how much DC licensing and maturation functionally overlap. CD40-CD40L interactions are not only crucial for upregulation of costimulatory molecules but also for DC survival (86). Additionally, mature DCs produce chemokines to attract other immune cells and to orchestrate the ongoing immune response. In contrast to maturation-induced upregulation of MHC II, CD1 trafficking is differentially regulated during DC maturation, and CD1 molecules are already expressed on immature DCs. While human DCs express all classes of CD1 molecules, murine DCs express only CD1d (87), which is crucial for DC-iNKT cell interactions. Trafficking studies showed that antigen presentation by CD1d to iNKT cells might already occur before DC maturation and MHC II presentation (88). This notion hinted to a possible role of iNKT cells as immunological helper cells.

\section{iNKT Cells as Immunological Helper Cells}

$\alpha$ GalCer was found to mediate CD40-dependent activation of CTL by NKT cell-helped DC (89), directing attention to the adjuvant activity for this agent. Furthermore, $\alpha$ GalCer also induced resistance to tumors and intracellular pathogens (25). Compared to CD40 ligation, LPS, and CpG, $\alpha$ GalCer induced equally high levels of CD40, CD80, CD86, MHC II, and DEC205 in CD11c ${ }^{+} \mathrm{CD}^{+} \mathrm{a}^{+}$and CD11c ${ }^{+} \mathrm{CD} 8 \mathrm{a}^{-} \mathrm{DCs}$, but was unable to induce DC maturation from bone marrow progenitors. Rather than acting directly on DCs, $\alpha$ GalCer mediated DC maturation through iNKT cells in a MyD88-independent manner. Combining $\alpha$ GalCer with CD40 stimulation caused DC to produce high amounts of IL12p70, while LPS and CD40 stimulation showed no such effect. IL12p70 production might explain the results of another study (90), where the simultaneous administration of OVA and $\alpha$ GalCer enhanced Th and CTL responses in an iNKT cell-dependent manner. A close temporal association between $\alpha$ GalCer and OVA-derived peptides and additional experiments with antigen-loaded DCs led to the conclusion that $\alpha \mathrm{GalCer}$ and peptides must reach the same DC. Formal in vivo evidence for such a tripartite cellular interaction was provided with the use of bm1/CD1d bone marrow chimeras (91). In addition, there was synergy when Th and iNKT help were combined. The means by which iNKT cells license DCs are not fully understood but in addition to providing CD40L to DCs, iNKT cells may act by promoting cross-talk of XCR $1^{+}$DCs and plasmacytoid DC (92) or by abundant cytokine production upon activation. Whether iNKT cells play a role as helper cells when activated by less potent ligands remains to be elucidated.

\section{iNKT Cells Help in CTL and CD8 ${ }^{+}$Memory T Cell Formation}

The knowledge on mechanisms iNKT cells use to substitute $\mathrm{CD} 4^{+}$ $\mathrm{T}$ cell help for antibody production, CTL generation, or memory formation is central for developing new vaccination strategies. An unresolved question is why some groups observed NKT cell-dependent reduction of CTL-mediated autoimmune diseases, whereas NKT cell-licensed DC induced strong CTL responses against tumors and viruses in other studies. The most obvious difference is the use of a single low dose of $\alpha \mathrm{GalCer}$ for induction of protective CTL responses and the use of multiple doses or high single doses of $\alpha \mathrm{GalCer}$ to inhibit unwanted T cell responses (93). In some clinical trials, $\alpha \mathrm{GalCer}$ was used to treat cancer, and human $\mathrm{CD} 4^{+}$iNKT cells expanded predominantly during early stages (26). CD4 ${ }^{+}$iNKT cells can induce IL12p70 production by DC and thereby Th1 polarization (93). Double negative (DN) iNKT cells expanded later after $\alpha \mathrm{GalCer}$ treatment and can induce apoptosis in $\alpha$ GalCer-loaded DC, thereby limiting the immune response (26). Functional differences between iNKT cell subsets in regards to cytokine production are evident both in mice and humans (94), but the effects on DC maturation, apoptosis, and CTL generation remain to be elucidated (Figure 1). A high frequency of a DN iNKT cell subset and their potential to lyse DCs may impair treatment of cancer patients and vaccination strategies. The role of iNKT cells during viral infections and the use of $\alpha \mathrm{GalCer}$ as vaccine adjuvant in the context of influenza infections have been reviewed recently in Ref. $(14,95)$. $\alpha$ GalCer increased the levels of influenza-specific systemic IgG and mucosal IgA antibodies, even in the absence of Th cells and antigen-specific CTL responses $(14,95)$. In contrast, after combined iNKT cell activation and influenza virus vaccination, an impaired CTL response but enhanced memory CTL generation was seen (96). In line with this, enhanced CTL memory differentiation during viral infection was also shown previously (97). Another study showed that iNKT cell enrichment in the CNS during Theiler's murine encephalomyelitis virus (TEMV) infection inhibited the antiviral CTL response and delayed the accumulation of TEMVspecific CTL. Also, the magnitude of the TEMV-specific CTL response was impaired (98). CTL memory formation was not assessed in that study. Co-administration of $\alpha \mathrm{GalCer}$ with suboptimal doses of irradiated sporozoites or recombinant viruses expressing a malaria antigen enhanced protective anti-malaria immunity in mice, and co-administration of $\alpha \mathrm{GalCer}$ with various immunogens enhanced antigen-specific CTL responses and Th1 responses (99). In conclusion, vaccination with $\alpha$ GalCer as adjuvant induced iNKT cell help for DCs, which promoted CTL memory formation but impaired primary antigen-specific CTL responses.

Before we can fully understand the mechanisms of iNKT cell help in CTL formation and memory generation, it is crucial to know how "help" influences CTL responses in general. Many reports about Th help are available and most of them show a diverse picture of the requirement for $\mathrm{CD} 4^{+} \mathrm{T}$ cell help in primary and/or secondary infections. Th help seems to be crucial for the clearance of some primary virus infections like HSV or influenza that do not affect DCs directly $(100,101)$, while in some viral 

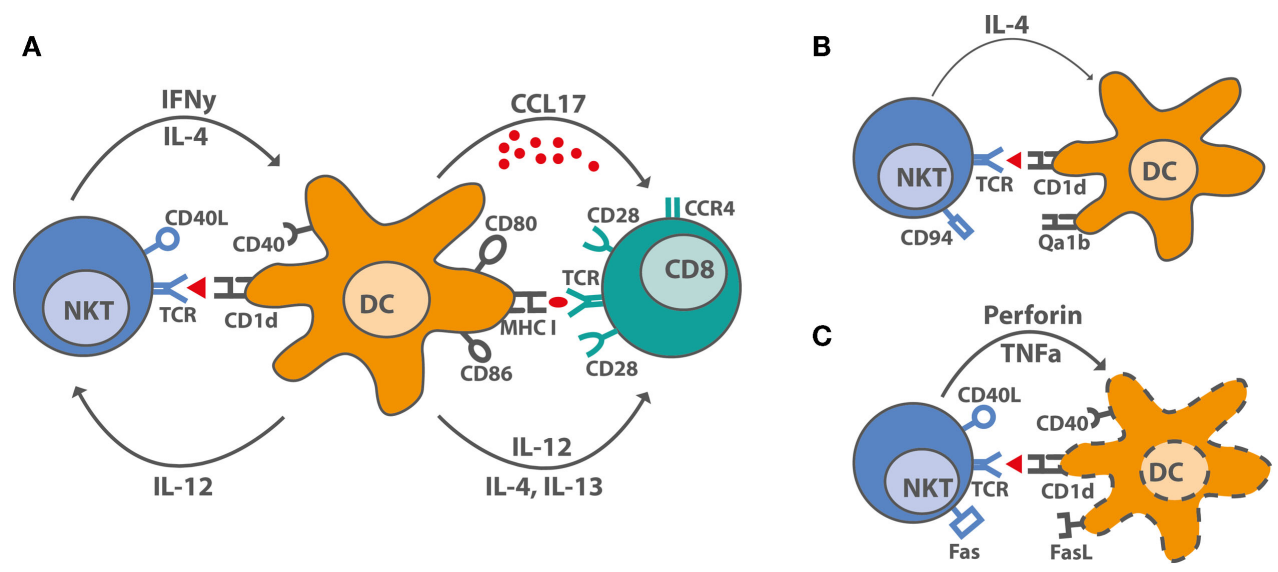

FIGURE 1 | iNKT cell-DC interactions after stimulation with $\alpha$ GalCer. (A) Under optimal stimulatory conditions, iNKT cells produce $\mathrm{IL}-4$, large amounts of IFN $\gamma$ and upregulate CD40L, thereby inducing maturation in DC. DC maturation leads to increased costimulatory capacity through upregulation of CD80 and CD86, of MHC molecules, and by producing the pro-inflammatory cytokine, IL-12, and the chemokine, CCL17. CCL17 attracts CCR4 ${ }^{+}$cells, including CD8 ${ }^{+}$
T cells, which can be activated by the licensed DC. (B) Overstimulated iNKT cells upregulate inhibitory receptors like CD94 and are incapable of producing IFN $\gamma$. DC interacing with hyporesponsive iNKT cells cannot be activated and do not induce $\mathrm{CD}^{+}{ }^{+} \mathrm{T}$ cell activation. (C) Some activated iNKT cells induce DC lysis rather than maturation by yet unknown mechanisms. Proposed mechanisms suggest a role for TNF $\alpha$, perforin, Fas-FasL interactions, and even CD40-CD40L. infections, Th help can be overcome (102). Additionally, CTL responses against minor $\mathrm{H}$ antigens, soluble proteins, tumors, and peptide-pulsed DC require Th help for the induction of optimal primary responses $(79,103,104)$. Some groups disagreed whether Th help was needed during secondary responses for proper reexpansion of CTL $(105,106)$ or whether Th help was merely a prerequisite during primary infections for CTL memory formation (107). Additionally, Th help was dispensable for the expansion, but not for the cytotoxic capacity of CTL in tuberculosis (108).

These differential observations may be explained not only by the variance of pathogens and model antigens used but also by different experimental setups. Moreover, Th dependency was studied by using $\mathrm{CD}^{-1-}$ mice, $\mathrm{MHC} \mathrm{II}^{-1-}$ mice, or CD4depleting antibodies, which are not biologically equivalent (109). For example, CD4-depleting antibodies also deplete regulatory T cells, $\mathrm{CD}^{+}{ }^{+} \mathrm{NKT}$ cells, and $\mathrm{CD} 4^{+}$DCs. However, most older studies agreed that the requirement for Th help is not a CTLintrinsic property but dependent on the infectious agent and DC maturation. Given the huge discrepancies in studies on Th help requirements, observations in a single model do not permit general conclusions on how $\mathrm{CD} 4^{+}$help may be substituted by iNKT cells. A deeper insight into CTL generation and memory formation is required to allow predictions for the role of iNKT cell help in CTL responses.

As reviewed previously in Ref.(110), CTL in primary responses can be divided into short-lived effector cells (SLEC) that mostly die off during the contraction phase and memory precursor cells (MPEC) that received less stimulation but more survival signals $(111,112)$. Even a single naive CTL can differentiate into a diverse population of effector and memory cells $(113,114)$ by multiple mechanisms, which have been reviewed in detail by Kaech and Cui (115). Prolonged antigen exposure and pro-inflammatory cytokines like IL-12 and IL-2 promote terminal differentiation of CTL and induce superior cytotoxic capacities (116-118). NKT cells may affect CTL differentiation other than Th cells, but this hypothesis requires further experimental exploration.

\section{iNKT Cells and Chemokines in CTL and $\mathrm{CD8}^{+} \mathrm{T}$ Cell Memory Formation}

Chemokines play a major role in orchestrating primary and memory CTL responses. During infections, CTL upregulated CXCR3, which allowed them to enter peripheral tissues (119). Th help was required for enhanced recruitment of CTL to the site of infection in some situations (120) by promoting CXCL9 and CXCL10 production, with CXCL9 being especially important for rapid memory responses in the lymph node (121). Infections of the lung and intestine showed no requirement of Th help for migration as lung infections, e.g., by influenza induce on-site proliferation of CTL rather than recruitment $(122,123)$ but Th cells promoted development of lung-resident memory cells (124).

CXCR3 also drove CTL toward an effector fate rather than memory fate (125). In line with this, CXCR3 $\times$ CCR5 doubledeficient mice showed a decreased contraction phase and harbored more memory CTL, which were unable to migrate into tissues and to clear infections (126). In humans, CCR5 expression was associated with effector memory T cells, whereas CCR7 was predominantly expressed on naïve and central memory $\mathrm{T}$ cells and CCR6 expression was found on early effector memory T cells (127-129).

iNKT cell-helped DCs produced high amounts of CCL17, thereby attracting $\mathrm{CCR}^{+}{ }^{+}$lymphocytes (91). This contrasts the situation in classical Th cell-dependent cross-priming, where DCs produced CCR5 ligands to attract CTL for crosspriming. These chemokines synergically guided CTL toward those DCs that have presented relevant antigen to helper $\mathrm{T}$ cell 
subsets, and thereby facilitated the ensuing CTL response. Thus, CCR4- and CCR5-binding chemokines have been described as a new signal in $\mathrm{T}$ cell activation, distinct from signal 1 , antigen, and signal 2, costimulation (130).

CCR4 is traditionally considered to be associated with skin homing Th2 and memory CD4 ${ }^{+} \mathrm{T}$ cells (131-134), but also with the recruitment of Treg to the inflamed liver (135). Several studies in humans showed increased CCR4 expression also on CTL in cutaneous diseases (136-138). A CCR $4^{+} \mathrm{CD}^{+}$central memory subset has been described that was generated in the presence of IL-4 and produced IL4 and IL-13 upon restimulation (139). These cells were not cytotoxic and produced little IFN $\gamma$, features associated with a so-called Tc2 subset $(139,140)$. Kondo and Takiguchi showed that human CCR $4^{+} \mathrm{CD} 8{ }^{+} \mathrm{T}$ cells expressed less effector molecules like perforin or granzymes compared to CCR6 ${ }^{+}$early effector memory T cells, but produced more TNF $\alpha$ and IL- 4 than $\mathrm{CCR}^{+}$naïve or central memory $\mathrm{CD}^{+} \mathrm{T}$ cells. They concluded that $\mathrm{CCR} 4^{+} \mathrm{CD} 8^{+} \mathrm{T}$ cells are a "little more differentiated than $\mathrm{CCR}^{+}$central memory ones and less differentiated than CCR ${ }^{+}$ early effector memory ones" and that they can migrate into secondary lymphoid organs where they mature after interacting with DCs expressing CCR4 ligand (141). Since iNKT cells produce IL4 upon activation and induce CCL17 production by helped DC,

\section{References}

1. Parekh VV, Wilson MT, Van Kaer L. iNKT-cell responses to glycolipids. Crit Rev Immunol (2005) 25(3):183-213. doi:10.1615/CritRevImmunol.v25.i3.20

2. Bendelac A, Savage PB, Teyton L. The biology of NKT cells. Annu Rev Immunol (2007) 25:297-336. doi:10.1146/annurev.immunol.25.022106.141711

3. Godfrey DI, Kronenberg M. Going both ways: immune regulation via CD1ddependent NKT cells. J Clin Invest (2004) 114(10):1379-88. doi:10.1172/ JCI23594

4. Kumar V, Delovitch TL. Different subsets of natural killer T cells may vary in their roles in health and disease. Immunology (2014) 142(3):321-36. doi:10. 1111 /imm. 12247

5. Zeng Z, Castano AR, Segelke BW, Stura EA, Peterson PA, Wilson IA. Crystal structure of mouse CD1: an MHC-like fold with a large hydrophobic binding groove. Science (1997) 277(5324):339-45. doi:10.1126/science.277. 5324.339

6. Porcelli SA. The CD1 family: a third lineage of antigen-presenting molecules. Adv Immunol (1995) 59:1-98. doi:10.1016/S0065-2776(08)60629-X

7. Akbari O, Stock P, Meyer E, Kronenberg M, Sidobre S, Nakayama T, et al. Essential role of NKT cells producing IL-4 and IL-13 in the development of allergen-induced airway hyperreactivity. Nat Med (2003) 9(5):582-8. doi:10. 1038/nm851

8. Sharif S, Arreaza GA, Zucker P, Mi QS, Sondhi J, Naidenko OV, et al. Activation of natural killer $\mathrm{T}$ cells by alpha-galactosylceramide treatment prevents the onset and recurrence of autoimmune Type 1 diabetes. Nat Med (2001) 7(9):1057-62. doi:10.1038/nm0901-1057

9. Lee PT, Benlagha K, Teyton L, Bendelac A. Distinct functional lineages of human V(alpha)24 natural killer T cells. J Exp Med (2002) 195(5):637-41. doi:10.1084/jem.20011908

10. Li X, Fujio M, Imamura M, Wu D, Vasan S, Wong CH, et al. Design of a potent CD1d-binding NKT cell ligand as a vaccine adjuvant. Proc Natl Acad Sci U S A (2010) 107(29):13010-5. doi:10.1073/pnas.1006662107

11. Faveeuw C, Trottein F. Optimization of natural killer $\mathrm{T}$ cell-mediated immunotherapy in cancer using cell-based and nanovector vaccines. Cancer Res (2014) 74(6):1632-8. doi:10.1158/0008-5472.CAN-13-3504

12. Carreno LJ, Kharkwal SS, Porcelli SA. Optimizing NKT cell ligands as vaccine adjuvants. Immunotherapy (2014) 6(3):309-20. doi:10.2217/imt.13.175

13. Padte NN, Li X, Tsuji M, Vasan S. Clinical development of a novel CD1dbinding NKT cell ligand as a vaccine adjuvant. Clin Immunol (2011) 140(2):142-51. doi:10.1016/j.clim.2010.11.009 they might play a role in the development or restimulation of $\mathrm{CCR}^{+}{ }^{+} \mathrm{CD}^{+} \mathrm{T}$ cells. The physiological role of this subset in viral infections and tumors remains to be elucidated.

\section{Concluding Remarks}

CD4-helped DCs and NKT cell-helped DCs provide various costimulatory signals and cytokines deciding the fate of $\mathrm{CD} 8^{+} \mathrm{T}$ cells toward effector or memory. However, the set of chemokines produced by NKT cell-helped DCs attract different subsets of naïve or memory $\mathrm{CD}^{+} \mathrm{T}$ cells compared to chemokines produced by Th-helped DCs. Dissecting the role of those $\mathrm{CD} 8^{+} \mathrm{T}$ cells subsets in effector and memory responses directed against tumors and viral infections may facilitate developing effective NKT cell-based vaccines.

\section{Acknowledgments}

We thank Dr. Kristina Koch for help with artwork. This work was supported by the Deutsche Forschungsgemeinschaft (grants SFB704 and 645). EM is supported by the German National Academic Foundation. CK is a member of the Excellence-Cluster ImmunoSensation.

14. Ko SY, Ko HJ, Chang WS, Park SH, Kweon MN, Kang CY. Alphagalactosylceramide can act as a nasal vaccine adjuvant inducing protective immune responses against viral infection and tumor. J Immunol (2005) 175(5):3309-17. doi:10.4049/jimmunol.175.5.3309

15. Chackerian A, Alt J, Perera V, Behar SM. Activation of NKT cells protects mice from tuberculosis. Infect Immun (2002) 70(11):6302-9. doi:10.1128/IAI.70.11. 6302-6309.2002

16. Huang Y, Chen A, Li X, Chen Z, Zhang W, Song Y, et al. Enhancement of HIV DNA vaccine immunogenicity by the NKT cell ligand, alphagalactosylceramide. Vaccine (2008) 26(15):1807-16. doi:10.1016/j.vaccine. 2008.02.002

17. Kakimi K, Guidotti LG, Koezuka Y, Chisari FV. Natural killer T cell activation inhibits hepatitis B virus replication in vivo. J Exp Med (2000) 192(7):921-30. doi:10.1084/jem.192.7.921

18. Kopecky-Bromberg SA, Fraser KA, Pica N, Carnero E, Moran TM, Franck RW, et al. Alpha-C-galactosylceramide as an adjuvant for a live attenuated influenza virus vaccine. Vaccine (2009) 27(28):3766-74. doi:10.1016/j.vaccine.2009.03. 090

19. Veldt BJ, van der Vliet HJ, von Blomberg BM, van Vlierberghe $H$, Gerken G, Nishi N, et al. Randomized placebo controlled phase I/II trial of alphagalactosylceramide for the treatment of chronic hepatitis C. J Hepatol (2007) 47(3):356-65. doi:10.1016/j.jhep.2007.04.018

20. Woltman AM, Ter Borg MJ, Binda RS, Sprengers D, von Blomberg BM, Scheper RJ, et al. Alpha-galactosylceramide in chronic hepatitis B infection: results from a randomized placebo-controlled phase I/II trial. Antivir Ther (2009) 14(6):809-18. doi:10.3851/1295

21. Youn HJ, Ko SY, Lee KA, Ko HJ, Lee YS, Fujihashi K, et al. A single intranasal immunization with inactivated influenza virus and alpha-galactosylceramide induces long-term protective immunity without redirecting antigen to the central nervous system. Vaccine (2007) 25(28):5189-98. doi:10.1016/j.vaccine. 2007.04.081

22. Gonzalez-Aseguinolaza G, de Oliveira C, Tomaska M, Hong S, Bruna-Romero O, Nakayama T, et al. Alpha-galactosylceramide-activated Valpha 14 natural killer T cells mediate protection against murine malaria. Proc Natl Acad Sci U S A (2000) 97(15):8461-6. doi:10.1073/pnas.97.15.8461

23. Kawakami K, Kinjo Y, Yara S, Koguchi Y, Uezu K, Nakayama T, et al. Activation of Valpha14(+) natural killer T cells by alpha-galactosylceramide results in development of Th1 response and local host resistance in mice infected with Cryptococcus neoformans. Infect Immun (2001) 69(1):213-20. doi:10.1128/IAI.69.1.213-220.2001 
24. Schmieg J, Yang G, Franck RW, Tsuji M. Superior protection against malaria and melanoma metastases by a C-glycoside analogue of the natural killer T cell ligand alpha-Galactosylceramide. J Exp Med (2003) 198(11):1631-41. doi:10.1084/jem.20031192

25. Fujii S, Shimizu K, Smith C, Bonifaz L, Steinman RM. Activation of natural killer $\mathrm{T}$ cells by alpha-galactosylceramide rapidly induces the full maturation of dendritic cells in vivo and thereby acts as an adjuvant for combined CD4 and CD8 T cell immunity to a coadministered protein. J Exp Med (2003) 198(2):267-79. doi:10.1084/jem.20030324

26. Chang DH, Osman K, Connolly J, Kukreja A, Krasovsky J, Pack M, et al. Sustained expansion of NKT cells and antigen-specific T cells after injection of alpha-galactosyl-ceramide loaded mature dendritic cells in cancer patients. J Exp Med (2005) 201(9):1503-17. doi:10.1084/jem.20042592

27. Crowe NY, Smyth MJ, Godfrey DI. A critical role for natural killer T cells in immunosurveillance of methylcholanthrene-induced sarcomas. J Exp Med (2002) 196(1):119-27. doi:10.1084/jem.20020092

28. Giaccone G, Punt CJ, Ando Y, Ruijter R, Nishi N, Peters M, et al. A phase I study of the natural killer T-cell ligand alpha-galactosylceramide (KRN7000) in patients with solid tumors. Clin Cancer Res (2002) 8(12):3702-9.

29. Ishikawa A, Motohashi S, Ishikawa E, Fuchida H, Higashino K, Otsuji M, et al. A phase I study of alpha-galactosylceramide (KRN7000)-pulsed dendritic cells in patients with advanced and recurrent non-small cell lung cancer. Clin Cancer Res (2005) 11(5):1910-7. doi:10.1158/1078-0432.CCR-04-1453

30. Kim D, Hung CF, Wu TC, Park YM. DNA vaccine with alphagalactosylceramide at prime phase enhances anti-tumor immunity after boosting with antigen-expressing dendritic cells. Vaccine (2010) 28(45):7297-305. doi:10.1016/j.vaccine.2010.08.079

31. Kim YJ, Ko HJ, Kim YS, Kim DH, Kang S, Kim JM, et al. Alphagalactosylceramide-loaded, antigen-expressing B cells prime a wide spectrum of antitumor immunity. Int J Cancer (2008) 122(12):2774-83. doi:10.1002/ijc. 23444

32. Kobayashi E, Motoki K, Uchida T, Fukushima H, Koezuka Y. KRN7000, a novel immunomodulator, and its antitumor activities. Oncol Res (1995) 7(10-11):529-34.

33. Kunii N, Horiguchi S, Motohashi S, Yamamoto H, Ueno N, Yamamoto S, et al. Combination therapy of in vitro-expanded natural killer $\mathrm{T}$ cells and alphagalactosylceramide-pulsed antigen-presenting cells in patients with recurrent head and neck carcinoma. Cancer Sci (2009) 100(6):1092-8. doi:10.1111/j. 1349-7006.2009.01135.x

34. Motohashi S, Nagato K, Kunii N, Yamamoto H, Yamasaki K, Okita K, et al. A phase I-II study of alpha-galactosylceramide-pulsed IL-2/GM-CSF-cultured peripheral blood mononuclear cells in patients with advanced and recurrent non-small cell lung cancer. J Immunol (2009) 182(4):2492-501. doi:10.4049/ jimmunol.0800126

35. Nieda M, Okai M, Tazbirkova A, Lin H, Yamaura A, Ide K, et al. Therapeutic activation of Valpha24+Vbeta11+ NKT cells in human subjects results in highly coordinated secondary activation of acquired and innate immunity. Blood (2004) 103(2):383-9. doi:10.1182/blood-2003-04-1155

36. Shibolet O, Alper R, Zlotogarov L, Thalenfeld B, Engelhardt D, Rabbani E, et al. NKT and CD8 lymphocytes mediate suppression of hepatocellular carcinoma growth via tumor antigen-pulsed dendritic cells. Int J Cancer (2003) 106(2):236-43. doi:10.1002/ijc.11201

37. Silk JD, Hermans IF, Gileadi U, Chong TW, Shepherd D, Salio M, et al. Utilizing the adjuvant properties of CD1d-dependent NK T cells in T cellmediated immunotherapy. J Clin Invest (2004) 114(12):1800-11. doi:10.1172/ JCI22046

38. Teng MW, Westwood JA, Darcy PK, Sharkey J, Tsuji M, Franck RW, et al. Combined natural killer T-cell based immunotherapy eradicates established tumors in mice. Cancer Res (2007) 67(15):7495-504. doi:10.1158/0008-5472. CAN-07-0941

39. Uchida T, Horiguchi S, Tanaka Y, Yamamoto H, Kunii N, Motohashi S, et al. Phase I study of alpha-galactosylceramide-pulsed antigen presenting cells administration to the nasal submucosa in unresectable or recurrent head and neck cancer. Cancer Immunol Immunother (2008) 57(3):337-45. doi:10.1007/ s00262-007-0373-5

40. Hong S, Wilson MT, Serizawa I, Wu L, Singh N, Naidenko OV, et al. The natural killer T-cell ligand alpha-galactosylceramide prevents autoimmune diabetes in non-obese diabetic mice. Nat Med (2001) 7(9):1052-6. doi:10.1038/ nm0901-1052
41. Jahng AW, Maricic I, Pedersen B, Burdin N, Naidenko O, Kronenberg M, et al. Activation of natural killer T cells potentiates or prevents experimental autoimmune encephalomyelitis. J Exp Med (2001) 194(12):1789-99. doi:10. 1084/jem.194.12.1789

42. Naumov YN, Bahjat KS, Gausling R, Abraham R, Exley MA, Koezuka Y, et al. Activation of CD1d-restricted T cells protects NOD mice from developing diabetes by regulating dendritic cell subsets. Proc Natl Acad Sci U S A (2001) 98(24):13838-43. doi:10.1073/pnas.251531798

43. Singh AK, Wilson MT, Hong S, Olivares-Villagomez D, Du C, Stanic AK, et al. Natural killer T cell activation protects mice against experimental autoimmune encephalomyelitis. J Exp Med (2001) 194(12):1801-11. doi:10.1084/jem.194. 12.1801

44. Wang B, Geng YB, Wang CR. CD1-restricted NK T cells protect nonobese diabetic mice from developing diabetes. J Exp Med (2001) 194(3):313-20. doi:10.1084/jem.194.3.313

45. Furlan R, Bergami A, Cantarella D, Brambilla E, Taniguchi M, Dellabona $P$, et al. Activation of invariant NKT cells by alphaGalCer administration protects mice from MOG35-55-induced EAE: critical roles for administration route and IFN-gamma. Eur J Immunol (2003) 33(7):1830-8. doi:10.1002/eji. 200323885

46. Zeng D, Liu Y, Sidobre S, Kronenberg M, Strober S. Activation of natural killer $\mathrm{T}$ cells in NZB/W mice induces Th1-type immune responses exacerbating lupus. J Clin Invest (2003) 112(8):1211-22. doi:10.1172/JCI17165

47. Chiba A, Oki S, Miyamoto K, Hashimoto H, Yamamura T, Miyake S. Suppression of collagen-induced arthritis by natural killer T cell activation with $\mathrm{OCH}$, a sphingosine-truncated analog of alpha-galactosylceramide. Arthritis Rheum (2004) 50(1):305-13. doi:10.1002/art.11489

48. Chiba A, Kaieda S, Oki S, Yamamura T, Miyake S. The involvement of $\mathrm{V}$ (alpha) 14 natural killer $\mathrm{T}$ cells in the pathogenesis of arthritis in murine models. Arthritis Rheum (2005) 52(6):1941-8. doi:10.1002/art.21056

49. Kim HY, Kim HJ, Min HS, Kim S, Park WS, Park SH, et al. NKT cells promote antibody-induced joint inflammation by suppressing transforming growth factor betal production. J Exp Med (2005) 201(1):41-7. doi:10.1084/ jem.20041400

50. Kojo S, Seino K, Harada M, Watarai H, Wakao H, Uchida T, et al. Induction of regulatory properties in dendritic cells by Valpha14 NKT cells. J Immunol (2005) 175(6):3648-55. doi:10.4049/jimmunol.175.6.3648

51. Major AS, Singh RR, Joyce S, Van Kaer L. The role of invariant natural killer $\mathrm{T}$ cells in lupus and atherogenesis. Immunol Res (2006) 34(1):49-66. doi:10. 1385/IR:34:1:49

52. Yang JQ, Wen X, Liu H, Folayan G, Dong X, Zhou M, et al. Examining the role of CD1d and natural killer T cells in the development of nephritis in a genetically susceptible lupus model. Arthritis Rheum (2007) 56(4):1219-33. doi:10.1002/art.22490

53. Kinjo Y, Illarionov P, Vela JL, Pei B, Girardi E, Li X, et al. Invariant natural killer $\mathrm{T}$ cells recognize glycolipids from pathogenic Gram-positive bacteria. Nat Immunol (2011) 12(10):966-74. doi:10.1038/ni.2096

54. Chang YJ, Kim HY, Albacker LA, Lee HH, Baumgarth N, Akira S, et al. Influenza infection in suckling mice expands an NKT cell subset that protects against airway hyperreactivity. J Clin Invest (2011) 121(1):57-69. doi:10.1172/ JCI44845

55. Kinjo Y, Wu D, Kim G, Xing GW, Poles MA, Ho DD, et al. Recognition of bacterial glycosphingolipids by natural killer T cells. Nature (2005) 434(7032):520-5. doi:10.1038/nature03407

56. Mattner J, Debord KL, Ismail N, Goff RD, Cantu C III, Zhou D, et al. Exogenous and endogenous glycolipid antigens activate NKT cells during microbial infections. Nature (2005) 434(7032):525-9. doi:10.1038/nature03408

57. Kinjo Y, Tupin E, Wu D, Fujio M, Garcia-Navarro R, Benhnia MR, et al. Natural killer $\mathrm{T}$ cells recognize diacylglycerol antigens from pathogenic bacteria. Nat Immunol (2006) 7(9):978-86. doi:10.1038/ni1380

58. Kawano T, Cui J, Koezuka Y, Toura I, Kaneko Y, Motoki K, et al. CD1drestricted and TCR-mediated activation of valpha14 NKT cells by glycosylceramides. Science (1997) 278(5343):1626-9. doi:10.1126/science.278.5343. 1626

59. Mallevaey T, Selvanantham T. Strategy of lipid recognition by invariant natural killer T cells: 'one for all and all for one'. Immunology (2012) 136(3):273-82. doi:10.1111/j.1365-2567.2012.03580.x

60. Oki S, Miyake S. Invariant natural killer T (iNKT) cells in asthma: a novel insight into the pathogenesis of asthma and the therapeutic implication of 
glycolipid ligands for allergic diseases. Allergol Int (2007) 56(1):7-14. doi:10. 2332/allergolint.R-06-137

61. Brigl M, Bry L, Kent SC, Gumperz JE, Brenner MB. Mechanism of CD1drestricted natural killer $\mathrm{T}$ cell activation during microbial infection. Nat Immunol (2003) 4(12):1230-7. doi:10.1038/ni1002

62. Wesley JD, Tessmer MS, Chaukos D, Brossay L. NK cell-like behavior of Valpha14i NK T cells during MCMV infection. PLoS Pathog (2008) 4(7):e1000106. doi:10.1371/journal.ppat.1000106

63. Tyznik AJ, Tupin E, Nagarajan NA, Her MJ, Benedict CA, Kronenberg M. Cutting edge: the mechanism of invariant NKT cell responses to viral danger signals. J Immunol (2008) 181(7):4452-6. doi:10.4049/jimmunol.181.7.4452

64. Salio M, Speak AO, Shepherd D, Polzella P, Illarionov PA, Veerapen N, et al. Modulation of human natural killer T cell ligands on TLR-mediated antigenpresenting cell activation. Proc Natl Acad Sci U S A (2007) 104(51):20490-5. doi:10.1073/pnas.0710145104

65. Paget C, Mallevaey T, Speak AO, Torres D, Fontaine J, Sheehan KC, et al. Activation of invariant NKT cells by toll-like receptor 9-stimulated dendritic cells requires type I interferon and charged glycosphingolipids. Immunity (2007) 27(4):597-609. doi:10.1016/j.immuni.2007.08.017

66. Crowe NY, Coquet JM, Berzins SP, Kyparissoudis K, Keating R, Pellicci DG, et al. Differential antitumor immunity mediated by NKT cell subsets in vivo. J Exp Med (2005) 202(9):1279-88. doi:10.1084/jem.20050953

67. Lee YJ, Holzapfel KL, Zhu J, Jameson SC, Hogquist KA. Steady-state production of IL-4 modulates immunity in mouse strains and is determined by lineage diversity of iNKT cells. Nat Immunol (2013) 14(11):1146-54. doi:10.1038/ni. 2731

68. Michel ML, Keller AC, Paget C, Fujio M, Trottein F, Savage PB, et al. Identification of an IL-17-producing NK1.1(neg) iNKT cell population involved in airway neutrophilia. J Exp Med (2007) 204(5):995-1001. doi:10.1084/jem. 20061551

69. Li S, Joseph C, Becourt C, Klibi J, Luce S, Dubois-Laforgue D, et al. Potential role of IL-17-producing iNKT cells in type 1 diabetes. PLoS One (2014) 9(4):e96151. doi:10.1371/journal.pone.0096151

70. Webster KE, Kim HO, Kyparissoudis K, Corpuz TM, Pinget GV, Uldrich AP, et al. IL-17-producing NKT cells depend exclusively on IL-7 for homeostasis and survival. Mucosal Immunol (2014) 7(5):1058-67. doi:10.1038/mi.2013.122

71. Monteiro M, Almeida CF, Agua-Doce A, Graca L. Induced IL-17-producing invariant NKT cells require activation in presence of TGF-beta and IL-1beta. J Immunol (2013) 190(2):805-11. doi:10.4049/jimmunol.1201010

72. Lynch L, Nowak M, Varghese B, Clark J, Hogan AE, Toxavidis V, et al. Adipose tissue invariant NKT cells protect against diet-induced obesity and metabolic disorder through regulatory cytokine production. Immunity (2012) 37(3):574-87. doi:10.1016/j.immuni.2012.06.016

73. Schoenberger SP, van der Voort EI, Krietemeijer GM, Offringa R, Melief CJ, Toes RE. Cross-priming of CTL responses in vivo does not require antigenic peptides in the endoplasmic reticulum of immunizing cells. J Immunol (1998) 161(8):3808-12.

74. Sigal LJ, Crotty S, Andino R, Rock KL. Cytotoxic T-cell immunity to virusinfected non-haematopoietic cells requires presentation of exogenous antigen. Nature (1999) 398(6722):77-80. doi:10.1038/18038

75. den Haan JM, Lehar SM, Bevan MJ. CD8(+) but not CD8(-) dendritic cells cross-prime cytotoxic T cells in vivo. J Exp Med (2000) 192(12):1685-96. doi:10.1084/jem.192.12.1685

76. Kurts C, Robinson BW, Knolle PA. Cross-priming in health and disease. Nat Rev Immunol (2010) 10(6):403-14. doi:10.1038/nri2780

77. Smith CM, Wilson NS, Waithman J, Villadangos JA, Carbone FR, Heath WR, et al. Cognate CD4(+) T cell licensing of dendritic cells in CD8(+) T cell immunity. Nat Immunol (2004) 5(11):1143-8. doi:10.1038/ni1129

78. Lanzavecchia A. Immunology. Licence to kill. Nature (1998) 393(6684):413-4. doi: $10.1038 / 30845$

79. Bennett SR, Carbone FR, Karamalis F, Miller JF, Heath WR. Induction of a $\mathrm{CD} 8+$ cytotoxic $\mathrm{T}$ lymphocyte response by cross-priming requires cognate CD4+ T cell help. J Exp Med (1997) 186(1):65-70. doi:10.1084/jem.186.1.65

80. Ridge JP, Di Rosa F, Matzinger P. A conditioned dendritic cell can be a temporal bridge between a CD4+ T-helper and a T-killer cell. Nature (1998) 393(6684):474-8. doi:10.1038/30989

81. Schoenberger SP, Toes RE, van der Voort EI, Offringa R, Melief CJ. T-cell help for cytotoxic T lymphocytes is mediated by CD40-CD40L interactions. Nature (1998) 393(6684):480-3. doi:10.1038/31002
82. Pulendran B, Palucka K, Banchereau J. Sensing pathogens and tuning immune responses. Science (2001) 293(5528):253-6. doi:10.1126/science.1062060

83. Inohara N, Nunez G. NODs: intracellular proteins involved in inflammation and apoptosis. Nat Rev Immunol (2003) 3(5):371-82. doi:10.1038/nri1086

84. Geijtenbeek TB, van Vliet SJ, Engering A, t Hart BA, van Kooyk Y. Self- and nonself-recognition by C-type lectins on dendritic cells. Annu Rev Immunol (2004) 22:33-54. doi:10.1146/annurev.immunol.22.012703.104558

85. Rogers NC, Slack EC, Edwards AD, Nolte MA, Schulz O, Schweighoffer E, et al. Syk-dependent cytokine induction by Dectin-1 reveals a novel pattern recognition pathway for C type lectins. Immunity (2005) 22(4):507-17. doi:10. 1016/j.immuni.2005.03.004

86. Miga AJ, Masters SR, Durell BG, Gonzalez M, Jenkins MK, Maliszewski $\mathrm{C}$, et al. Dendritic cell longevity and $\mathrm{T}$ cell persistence is controlled by CD154-CD40 interactions. Eur J Immunol (2001) 31(3):959-65. doi:10.1002/ 1521-4141(200103)31:3<959::AID-IMMU959>3.0.CO;2-A

87. Barral DC, Brenner MB. CD1 antigen presentation: how it works. Nat Rev Immunol (2007) 7(12):929-41. doi:10.1038/nri2191

88. Gelin C, Sloma I, Charron D, Mooney N. Regulation of MHC II and CD1 antigen presentation: from ubiquity to security. J Leukoc Biol (2009) 85(2):215-24. doi: $10.1189 / \mathrm{jlb} .0308206$

89. Nishimura T, Kitamura H, Iwakabe K, Yahata T, Ohta A, Sato M, et al. The interface between innate and acquired immunity: glycolipid antigen presentation by CD1d-expressing dendritic cells to NKT cells induces the differentiation of antigen-specific cytotoxic T lymphocytes. Int Immunol (2000) 12(7):987-94. doi:10.1093/intimm/12.7.987

90. Hermans IF, Silk JD, Gileadi U, Salio M, Mathew B, Ritter G, et al. NKT cells enhance $\mathrm{CD} 4+$ and $\mathrm{CD} 8+\mathrm{T}$ cell responses to soluble antigen in vivo through direct interaction with dendritic cells. J Immunol (2003) 171(10):5140-7. doi:10.4049/jimmunol.171.10.5140

91. Semmling V, Lukacs-Kornek V, Thaiss CA, Quast T, Hochheiser K, Panzer $\mathrm{U}$, et al. Alternative cross-priming through CCL17-CCR4-mediated attraction of CTLs toward NKT cell-licensed DCs. Nat Immunol (2010) 11(4):313-20. doi:10.1038/ni.1848

92. Shimizu K, Asakura M, Shinga J, Sato Y, Kitahara S, Hoshino K, et al. Invariant NKT cells induce plasmacytoid dendritic cell (DC) cross-talk with conventional DCs for efficient memory CD8+ T cell induction. J Immunol (2013) 190(11):5609-19. doi:10.4049/jimmunol.1300033

93. Liu TY, Uemura Y, Suzuki M, Narita Y, Hirata S, Ohyama H, et al. Distinct subsets of human invariant NKT cells differentially regulate $\mathrm{T}$ helper responses via dendritic cells. Eur J Immunol (2008) 38(4):1012-23. doi:10. 1002/eji.200737838

94. Coquet JM, Chakravarti S, Kyparissoudis K, McNab FW, Pitt LA, McKenzie BS, et al. Diverse cytokine production by NKT cell subsets and identification of an IL-17-producing CD4-NK1.1- NKT cell population. Proc Natl Acad Sci U S A (2008) 105(32):11287-92. doi:10.1073/pnas.0801631105

95. Galli G, Pittoni P, Tonti E, Malzone C, Uematsu Y, Tortoli M, et al. Invariant NKT cells sustain specific B cell responses and memory. Proc Natl Acad Sci U S A (2007) 104(10):3984-9. doi:10.1073/pnas.0700191104

96. Guillonneau C, Mintern JD, Hubert FX, Hurt AC, Besra GS, Porcelli S, et al. Combined NKT cell activation and influenza virus vaccination boosts memory CTL generation and protective immunity. Proc Natl Acad Sci U S A (2009) 106(9):3330-5. doi:10.1073/pnas.0813309106

97. Reilly EC, Thompson EA, Aspeslagh S, Wands JR, Elewaut D, Brossay L. Activated iNKT cells promote memory CD8+ T cell differentiation during viral infection. PLoS One (2012) 7(5):e37991. doi:10.1371/journal.pone.0037991

98. Mars LT, Mas M, Beaudoin L, Bauer J, Leite-de-Moraes M, Lehuen A, et al. Invariant NKT cells regulate the $\mathrm{CD} 8 \mathrm{~T}$ cell response during Theiler's virus infection. PLoS One (2014) 9(1):e87717. doi:10.1371/journal.pone.0087717

99. Gonzalez-Aseguinolaza G, Van Kaer L, Bergmann CC, Wilson JM, Schmieg J, Kronenberg M, et al. Natural killer T cell ligand alpha-galactosylceramide enhances protective immunity induced by malaria vaccines. J Exp Med (2002) 195(5):617-24. doi:10.1084/jem.20011889

100. Jennings SR, Bonneau RH, Smith PM, Wolcott RM, Chervenak R. CD4positive $\mathrm{T}$ lymphocytes are required for the generation of the primary but not the secondary CD8-positive cytolytic $\mathrm{T}$ lymphocyte response to herpes simplex virus in C57BL/6 mice. Cell Immunol (1991) 133(1):234-52. doi:10. 1016/0008-8749(91)90194-G

101. Riberdy JM, Christensen JP, Branum K, Doherty PC. Diminished primary and secondary influenza virus-specific CD8(+) T-cell responses in CD4-depleted 
Ig(-/-) mice. J Virol (2000) 74(20):9762-5. doi:10.1128/JVI.74.20.9762-9765. 2000

102. Janssen EM, Lemmens EE, Wolfe T, Christen U, von Herrath MG, Schoenberger SP. CD4+ $\mathrm{T}$ cells are required for secondary expansion and memory in CD8+ T lymphocytes. Nature (2003) 421(6925):852-6. doi:10.1038/ nature 01441

103. Husmann LA, Bevan MJ. Cooperation between helper T cells and cytotoxic T lymphocyte precursors. Ann N Y Acad Sci (1988) 532:158-69. doi:10.1111/ j.1749-6632.1988.tb36335.x

104. Guerder S, Matzinger P. A fail-safe mechanism for maintaining self-tolerance. J Exp Med (1992) 176(2):553-64. doi:10.1084/jem.176.2.553

105. Di Rosa F, Matzinger P. Long-lasting CD8 T cell memory in the absence of CD4 T cells or B cells. J Exp Med (1996) 183(5):2153-63. doi:10.1084/jem.183. 5.2153

106. Bourgeois C, Veiga-Fernandes H, Joret AM, Rocha B, Tanchot C. CD8 lethargy in the absence of CD4 help. Eur J Immunol (2002) 32(8):2199-207. doi:10. 1002/1521-4141(200208)32:8<2199::AID-IMMU2199>3.0.CO;2-L

107. Marzo AL, Vezys V, Klonowski KD, Lee SJ, Muralimohan G, Moore M, et al. Fully functional memory CD8 T cells in the absence of CD4 T cells. J Immunol (2004) 173(2):969-75. doi:10.4049/jimmunol.173.2.969

108. Serbina NV, Lazarevic V, Flynn JL. CD4(+) T cells are required for the development of cytotoxic CD8(+) T cells during Mycobacterium tuberculosis infection. J Immunol (2001) 167(12):6991-7000. doi:10.4049/jimmunol.167.12.6991

109. Tyznik AJ, Sun JC, Bevan MJ. The CD8 population in CD4-deficient mice is heavily contaminated with MHC class II-restricted T cells. J Exp Med (2004) 199(4):559-65. doi:10.1084/jem.20031961

110. Zhang N, Bevan MJ. CD8(+) T cells: foot soldiers of the immune system. Immunity (2011) 35(2):161-8. doi:10.1016/j.immuni.2011.07.010

111. Mescher MF, Curtsinger JM, Agarwal P, Casey KA, Gerner M, Hammerbeck $\mathrm{CD}$, et al. Signals required for programming effector and memory development by CD8+ T cells. Immunol Rev (2006) 211:81-92. doi:10.1111/j. 0105-2896.2006.00382.x

112. Parish IA, Kaech SM. Diversity in CD8(+) T cell differentiation. Curr Opin Immunol (2009) 21(3):291-7. doi:10.1016/j.coi.2009.05.008

113. Stemberger C, Neuenhahn M, Buchholz VR, Busch DH. Origin of CD8+ effector and memory T cell subsets. Cell Mol Immunol (2007) 4(6):399-405.

114. Gerlach C, van Heijst JW, Swart E, Sie D, Armstrong N, Kerkhoven RM, et al. One naive T cell, multiple fates in CD8+ T cell differentiation. J Exp Med (2010) 207(6):1235-46. doi:10.1084/jem.20091175

115. Kaech SM, Cui W. Transcriptional control of effector and memory CD8+ T cell differentiation. Nat Rev Immunol (2012) 12(11):749-61. doi:10.1038/ nri3307

116. Curtsinger JM, Johnson CM, Mescher MF. CD8 T cell clonal expansion and development of effector function require prolonged exposure to antigen, costimulation, and signal 3 cytokine. J Immunol (2003) 171(10):5165-71. doi:10.4049/jimmunol.171.10.5165

117. Pearce EL, Shen H. Generation of CD8 T cell memory is regulated by IL-12. J Immunol (2007) 179(4):2074-81. doi:10.4049/jimmunol.179.4.2074

118. Pipkin ME, Sacks JA, Cruz-Guilloty F, Lichtenheld MG, Bevan MJ, Rao A. Interleukin-2 and inflammation induce distinct transcriptional programs that promote the differentiation of effector cytolytic T cells. Immunity (2010) 32(1):79-90. doi:10.1016/j.immuni.2009.11.012

119. Groom JR, Luster AD. CXCR3 in T cell function. Exp Cell Res (2011) 317(5):620-31. doi:10.1016/j.yexcr.2010.12.017

120. Nakanishi Y, Lu B, Gerard C, Iwasaki A. CD8(+) T lymphocyte mobilization to virus-infected tissue requires CD4(+) T-cell help. Nature (2009) 462(7272):510-3. doi:10.1038/nature08511

121. Kastenmuller W, Brandes M, Wang Z, Herz J, Egen JG, Germain RN. Peripheral prepositioning and local CXCL9 chemokine-mediated guidance orchestrate rapid memory $\mathrm{CD} 8+\mathrm{T}$ cell responses in the lymph node. Immunity (2013) 38(3):502-13. doi:10.1016/j.immuni.2012.11.012

122. Bedoui S, Gebhardt T. Interaction between dendritic cells and $T$ cells during peripheral virus infections: a role for antigen presentation beyond lymphoid organs? Curr Opin Immunol (2011) 23(1):124-30. doi:10.1016/j.coi.2010.11. 001

123. McGill J, Legge KL. Cutting edge: contribution of lung-resident T cell proliferation to the overall magnitude of the antigen-specific CD8 $\mathrm{T}$ cell response in the lungs following murine influenza virus infection. J Immunol (2009) 183(7):4177-81. doi:10.4049/jimmunol.0901109

124. Laidlaw BJ, Zhang N, Marshall HD, Staron MM, Guan T, Hu Y, et al. CD4+ $\mathrm{T}$ cell help guides formation of CD103+ lung-resident memory CD8+ T cells during influenza viral infection. Immunity (2014) 41(4):633-45. doi:10.1016/ j.immuni.2014.09.007

125. Kurachi M, Kurachi J, Suenaga F, Tsukui T, Abe J, Ueha S, et al. Chemokine receptor CXCR3 facilitates CD8(+) T cell differentiation into short-lived effector cells leading to memory degeneration. J Exp Med (2011) 208(8):1605-20. doi:10.1084/jem.20102101

126. Kohlmeier JE, Reiley WW, Perona-Wright G, Freeman ML, Yager EJ, Connor LM, et al. Inflammatory chemokine receptors regulate CD8(+) T cell contraction and memory generation following infection. J Exp Med (2011) 208(8):1621-34. doi:10.1084/jem.20102110

127. Tomiyama H, Matsuda T, Takiguchi M. Differentiation of human CD8(+) $\mathrm{T}$ cells from a memory to memory/effector phenotype. J Immunol (2002) 168(11):5538-50. doi:10.4049/jimmunol.168.11.5538

128. Sallusto F, Geginat J, Lanzavecchia A. Central memory and effector memory T cell subsets: function, generation, and maintenance. Annu Rev Immunol (2004) 22:745-63. doi:10.1146/annurev.immunol.22.012703.104702

129. Tomiyama H, Takata H, Matsuda T, Takiguchi M. Phenotypic classification of human CD8+ $\mathrm{T}$ cells reflecting their function: inverse correlation between quantitative expression of CD27 and cytotoxic effector function. Eur J Immunol (2004) 34(4):999-1010. doi:10.1002/eji.200324478

130. Bousso P, Albert ML. Signal 0 for guided priming of CTLs: NKT cells do it too. Nat Immunol (2010) 11(4):284-6. doi:10.1038/ni0410-284

131. Vestergaard C, Bang K, Gesser B, Yoneyama H, Matsushima K, Larsen CGA Th2 chemokine, TARC, produced by keratinocytes may recruit CLA+CCR4+ lymphocytes into lesional atopic dermatitis skin. J Invest Dermatol (2000) 115(4):640-6. doi:10.1046/j.1523-1747.2000.00115.x

132. Nakatani T, Kaburagi Y, Shimada Y, Inaoki M, Takehara K, Mukaida N, et al. CCR4 memory CD4+ T lymphocytes are increased in peripheral blood and lesional skin from patients with atopic dermatitis. J Allergy Clin Immunol (2001) 107(2):353-8. doi:10.1067/mai.2001.112601

133. Kusumoto M, Xu B, Shi M, Matsuyama T, Aoyama K, Takeuchi T. Expression of chemokine receptor CCR4 and its ligands (CCL17 and CCL22) in murine contact hypersensitivity. J Interferon Cytokine Res (2007) 27(11):901-10. doi:10.1089/jir.2006.0064

134. Gehad A, Al-Banna NA, Vaci M, Issekutz AC, Mohan K, Latta M, et al. Differing requirements for CCR4, E-selectin, and alpha4betal for the migration of memory CD4 and activated T cells to dermal inflammation. J Immunol (2012) 189(1):337-46. doi:10.4049/jimmunol.1102315

135. Oo YH, Shetty S, Adams DH. The role of chemokines in the recruitment of lymphocytes to the liver. Dig Dis (2010) 28(1):31-44. doi:10.1159/000282062

136. Teraki Y, Miyake A, Takebayashi R, Shiohara T. Homing receptor and chemokine receptor on intraepidermal T cells in psoriasis vulgaris. Clin Exp Dermatol (2004) 29(6):658-63. doi:10.1111/j.1365-2230.2004.01638.x

137. Wenzel J, Henze S, Worenkamper E, Basner-Tschakarjan E, SokolowskaWojdylo M, Steitz J, et al. Role of the chemokine receptor CCR4 and its ligand thymus- and activation-regulated chemokine/CCL17 for lymphocyte recruitment in cutaneous lupus erythematosus. J Invest Dermatol (2005) 124(6):1241-8. doi:10.1111/j.0022-202X.2005.23755.x

138. Seneviratne SL, Black AP, Jones L, Bailey AS, Ogg GS. The role of skin-homing T cells in extrinsic atopic dermatitis. QJM (2007) 100(1):19-27. doi:10.1093/ qjmed/hcl132

139. Geginat J, Lanzavecchia A, Sallusto F. Proliferation and differentiation potential of human CD8+ memory T-cell subsets in response to antigen or homeostatic cytokines. Blood (2003) 101(11):4260-6. doi:10.1182/ blood-2002-11-3577

140. Le Gros G, Erard F. Non-cytotoxic, IL-4, IL-5, IL-10 producing CD8+ T cells: their activation and effector functions. Curr Opin Immunol (1994) 6(3):453-7. doi:10.1016/0952-7915(94)90127-9

141. Kondo T, Takiguchi M. Human memory CCR4+CD8+ T cell subset has the ability to produce multiple cytokines. Int Immunol (2009) 21(5):523-32. doi:10.1093/intimm/dxp019

Conflict of Interest Statement: The authors declare that the research was conducted in the absence of any commercial or financial relationships that could be construed as a potential conflict of interest.

Copyright (c) 2015 Gottschalk, Mettke and Kurts. This is an open-access article distributed under the terms of the Creative Commons Attribution License (CC BY). The use, distribution or reproduction in other forums is permitted, provided the original author(s) or licensor are credited and that the original publication in this journal is cited, in accordance with accepted academic practice. No use, distribution or reproduction is permitted which does not comply with these terms. 